\title{
Oleanolik asidin çekal ligasyon ve punksiyon ile sepsis oluşturulan ratlarda kalp hasarı üzerine etkileri
}

\author{
Hüseyin Serkan Erol ${ }^{1 *}(0)$, Tuba Aydın² (-), Serkan Yıldırım ${ }^{3}(0)$, Mohammad Alhilal $^{4}(0)$ \\ Muhammet Bahaeddin Dörtbudak ${ }^{5}$ (), Kübra Coşar ${ }^{(1)}$, Mesut Bünyami Halıcı ${ }^{7}$ (-)
}

\author{
${ }^{1}$ Kastamonu Üniversitesi, Veteriner Fakültesi, Biyokimya Anabilim Dalı, Kastamonu, Türkiye \\ ${ }^{2}$ Ağrı Ibrahim Çeçen Üniversitesi, Eczacılık Fakültesi, Farmakognozi Anabilim Dalı, Ağrı, Türkiye \\ ${ }^{3}$ Atatürk Üniversitesi, Veteriner Fakültesi, Patoloji Anabilim Dalı, Erzurum, Türkiye \\ ${ }^{4}$ Atatürk Üniversitesi, Veteriner Fakültesi, Biyokimya Anabilim Dalı, Erzurum, Türkiye \\ ${ }^{5}$ Atatürk Üniversitesi, Veteriner Fakültesi, Patoloji Anabilim Dalı, Erzurum, Türkiye \\ ${ }^{6}$ Atatürk Üniversitesi, Veteriner Fakültesi, Biyokimya Anabilim Dalı, Erzurum, Türkiye \\ ${ }^{7}$ Atatürk Üniversitesi, Veteriner Fakültesi, Biyokimya Anabilim Dalı, Erzurum, Türkiye
}

Geliş Tarihi / Received: 09.10.2020, Kabul tarihi / Accepted: 30.10 .2020

\begin{abstract}
Özet: Bu çalışmada zeytin ağacı (Olea europeae) ağacının yaprağından saflaştırılan oleanolik asidin (OEA) ratlarda çekal ligasyon ve punksiyonla (CLP) indüklenen sepisisin oluşturduğu kalp hasarı üzerine etkileri incelendi. Her gruba eşit olacak şekilde 30 adet Wistar erkek rat sham, sepsis, OEA-150, OEA-300 ve CEFT olarak 5 gruba ayrıldı. Kromatografik metotlarla zeytin yaprağından saflaştırılan oleanolik asit OEA gruplarına 150 ve 300 mg/kg dozlarda oral yolla uygulandı. CEFT grubuna seftriakson $150 \mathrm{mg} / \mathrm{kg}$ dozda intraperitoneal yolla uygulandı. Uygulamadan 24 saat sonra ratlardan kan serumu ve kalp dokuları, histopatolojik, immünohistokimyasal ve biyokimyasal analizler için alındı. Yapılan histopatolojik ve immünohistokimyasal incelemede, sepsis grubunun doku tümör nekrozis faktör (TNF)- $\alpha$ ve interlökin (IL)-1 $\beta$ ekspresyonlarında artış, myokartta kas liflerinde şiddetli düzeyde hyalin dejenerasyon, Zenker nekrozu ve damarlarda şiddetli düzeyde hiperemi gözlendi. OEA ve seftriakson (CEFT) sitokin ekspresyonlarında ve histopatolojik bulgularda azalma sağladı. Sepsis, doku superoksit dismutaz aktivitesini (SOD) azalttı. Ayrıca lipid peroksidasyonu (LPO) ve glutatyon (GSH) seviyeleri ile doku katalaz (KAT), serum kreatin kinaz (CK-MB) ve serum laktat dehidrojenaz (LDH) aktivitelerini önemli şekilde arttırdı. OEA ve CEFT, SOD aktivitesini önemli derecede arttırırken diğer parametrelerde belirgin düşüşe neden oldu. Bu çalışmadan elde edilen bulgular ışığında oleanolik asidin sepsis sırasında oluşan kalp dokusu hasarının azaltılmasında faydalı olabileceği düşünülmektedir.
\end{abstract}

Anahtar kelimeler: Inflamasyon, Kalp, Oleanolik asit, Seftriakson, Sepsis.

\section{The effects of oleanolic acid on heart injury in cecal ligation and puncture-induced sepsis in rats}

\begin{abstract}
In the present, the effects of oleanolic acid (OEA) purified from leaf of the olive tree (Olea europeae) on heart damage caused by cecal ligation and puncture (CLP) induced sepsis model in rats were examined. Thirty Wistar rats equally were divided into six groups as sham, sepsis, OEA-150, OEA-300 and CEFT. Oleanolic acid purified from olive leaf by chromatographic methods was orally administered at doses of 150 and $300 \mathrm{mg} / \mathrm{kg}$ to OEA groups. Ceftriaxone was intraperitoneally administered at a dose of $150 \mathrm{mg} / \mathrm{kg}$ to the CEFT group. Twenty-four hours after the application, blood serum and heart tissues were taken from rats for histopathological, immunohistochemical and biochemical analysis. In histopathological and immunohistochemical examination, an increase in tissue tumor necrosis factor (TNF)- $\alpha$ and interleukin (IL)-1 $\beta$ expressions of the sepsis group, severe hyaline degeneration in muscle fibers in the myocardium, Zenker necrosis and severe hyperemia in the vessels were observed. OEA and ceftriaxone (CEFT) provided a decrease in cytokine expressions and histopathological findings. Sepsis reduced tissue superoxide dismutase activity (SOD). It also significantly increased lipid peroxidation (LPO), glutathione (GSH) levels, catalase (CAT), serum creatine kinase (CK-MB) and serum lactate dehydrogenase (LDH) activities. OEA and CEFT significantly increased SOD activity while causing a significant decrease in other parameters. In the light of the findings from this study, it is thought that oleanolic acid may be beneficial in reducing heart tissue damage during sepsis.
\end{abstract}

Keywords: Ceftriaxone, Heart, Inflammation, Oleanolic acid, Sepsis.

\section{Giriş}

Sepsis, enfeksiyona bağlı olarak gelişen sistemik inflamatuvar yanıt ve çoklu organ yetmezliği ile seyreden ölümcül bir sendromudur. Ayrıca yoğun bakım ölümlerinin en önemli sebeplerinden biridir. Türkiye'de bu oranlar ağır sepsis vakalarında \%55.7,

Yazışma adresi / Correspondence: Hüseyin Serkan Erol, Kastamonu Üniversitesi Veteriner Fakültesi Oda no:117 Kastamonu E-Posta: hserol@kastamonu.edu.tr

ORCID IDs of the authors: ${ }^{10000-0002-9121-536 X ~ • ~}{ }^{200000-0002-7653-6480 ~ • ~}{ }^{3} 0000-0003-2457-3367 \cdot{ }^{4} 0000-0002-2832-$

$8409 \cdot{ }^{5} 0000-0001-5777-964 X \cdot{ }^{6} 0000-0002-8237-0739 \cdot{ }^{700000-0002-7473-2955 ~}$ 
septik şok vakalarında ise \%70.4 olduğu rapor edilmiştir (Baykara ve ark. 2018). Sepsis koagulasyon mekanizmasında aksaklıklar meydana getirerek mikrovaskülar konjesyon ve iskemiye neden olur. Bu durum doku hasarı ve ölümünün temellerini oluşturur (Simmons ve Pittet 2015). Sepsis için uygulanan tedaviler her ne kadar hastalığın belirtilerini azaltsa da tedavi sonrası organlarda kalıcı hasarlar meydana gelmektedir. Sepsis sırasında organ ve dokularda meydana gelen yıkım; sepsis sonrası dönemde önemli doku veya organ kayıpları, uzun dönem tedavi ihtiyacı ve kronik hastalıklar gibi risklerin ortaya çıkmasına neden olur (Winters ve ark. 2010). Bu nedenle sepsis sırasında doku ve organların korunarak hasar oluşumunu önlemek tedavi sonrasında bu riskleri azaltabilmektedir.

Şiddetlenen sistemik inflamatuvar yanıt kalp gibi hayati organlarda oksidatif stresi meydana getirir. Oksidatif streste artan süperoksit $\left(\mathrm{O}_{2}^{-}\right)$, peroksil $\left(\mathrm{RO}_{2}\right)$ ve hidroksil $\left(\mathrm{OH}^{-}\right)$radikalleri gibi reaktif oksijen türleri (ROS) hücresel membranlarda bulunan fosfolipidlerin yanı sıra yapısal proteinler ve hatta DNA'da hasar meydana getirir. Bu durum apoptozisi tetikler ve yaygın doku hasarına sebep olur. Ayrıca dokularda TNF- $\alpha$ ve IL-1 $\beta$ gibi proinflamatuvar sitokinlerin ekspresyonlarını ve salınımını arttırı. Sitokin salınımı önce nötrofillerin ve mononükleer hücrelerin aktivasyonunu, sonrasında ise bu hücrelerin doku içine göçünü sağlar (Cadirci ve ark. 2010). Sepsiste ilerleyen inflamatuvar süreç ROS'ler ile güçlenerek sitokin kaskadı olarak da isimlendirilen git gide güçlenen sitokin fırtınasına dönüşür (Chousterman ve ark. 2017). Bu sebeple son yıllarda sepsisin tedavisi ile ilgili yapılan çalışmalarda sitokin salınımını azaltmanın yanı sıra ROS oluşumunun da engellenmesinin sepsis sonucu meydana gelen doku ve organ hasarının azalttığını ve ayrıca mortalite oranını da düşürdüğü bildirilmektedir (Yun ve ark. 2009; Cadirci ve ark. 2010; Petronilho ve ark. 2016).

Oleanoleik asit (OEA) zeytin yağında ve yaprağında bulunan pentasiklik triterpen yapısında bir moleküldür ve kimyasal olarak 3ß-hidroksi-olea-12-en-28-oik asit şeklinde isimlendirilir (Liu 1995). Daha önceki çalışmalarda OEA ve türevlerinin güçlü antioksidan, anti-inflamatuvar, antikolinesteraz, hepatoprotektif, antikanser, nöroprotektif ve immünmodülatör gibi birçok özelliklere sahip olduğu bildirilmiştir (Liu 1995, 2005; Topçu ve ark. 2013).

Sepsis tedavisinde çok çeşitli medikal tedaviler denenmiş olsa da meydana gelen yaygın doku hasarını önleyecek yeterli bir tedavi hala bulunmamaktadır. Ancak sepsis ile ilişkili mekanizmaların aydınlatılmasıyla daha etkili bir tedavi geliştirilebi- lecektir. Bu sebeple mevcut çalışmada OEA'nın çekal ligasyon ve punksiyon (CLP) yöntemiyle oluşturulan sepsisin kalp dokusu üzerine etkilerinin oksidatif stres ve inflamasyon parametreleri üzerinden biyokimyasal ve histopatolojik yöntemlerle araştırılması amaçlanmıştır. Ayrıca oksidatif stres ile inflamasyon arasındaki ilişkiyi ortaya koymak için kalp dokusunun bazı antioksidan parametreleri ile inflamatuvar sitokinlerindeki değişimler incelenmiştir.

\section{Gereç ve Yöntem}

\section{Oleanolik asit molekülünün saflaştırılması ve moleküler identifikasyonu}

Çalışmada kullanılan OEA, daha önce Kısa ve ark. (2018) tarafından belirtilen şekilde, kromatografik yöntemler kullanılarak saflaştırıldı ve doğrulandı. İnce tabaka kromatografisi (TLC) için hazır silika jel 60 (60F-254, Merck, ABD) kullanıldı. Oluşan spotlar sülfik asit içinde hazırlanan \%1'lik vanilin çözeltisi ile $110^{\circ} \mathrm{C}$ 'de Isıtılarak UV254 ve UV356 dalga boylarında görünür hale getirildi. Fourier dönüşümlü kızılötesi (FT-IR) spektroskopisi (Nicolet iS10, Thermoscientific, ABD) kullanılarak $4000-400 \mathrm{~cm}-1$ dalga boylarında spektrumları kaydedildi. Madde yapılarının belirlenmesinde nüklear rezonans spektroskopisi (NMR) ile ${ }^{1} \mathrm{H}$ NMR ve ${ }^{13} \mathrm{C}$ NMR (400, Bruker, ABD) kullanıldı.

Çalışmada Eylül ayında Kilis bölgesinden toplanan zeytin ağacı (Olea europeae) yaprakları uluslararası teşhis yöntemleri kullanılarak Tuba Aydın tarafından teşhis edildi ve kurutulmaya bırakıldı. Toplanan yapraklar toz haline getirildi (300 gr) ve etil alkol ile 5 kez muamele edilerek ekstrakte edildi. Filtrasyondan sonra döner rotor bir evaporatör ile vakum altında etil alkol uzaklaştırıldı. Geriye kalan koyu kahverengi çökelti (85 gr) 4 kez $250 \mathrm{ml}$ etil asetat ile muamele edildi. Böylelikle etil asetatta çözünen ve çözünmeyen olarak iki faz elde edildi. Çözünen kısım (50.5 gr) $250 \mathrm{ml} \mathrm{n}$-hekzan ile 3 kere muamele edildi ve çözünmüş kısım uzaklaştııılarak geriye yeşilimsi amorf katı kısım (35 gr) kaldı. Bu kısımdan kolon kromatografisi ile silika jelde (250 gr, Merck, 70-230 mesh, ABD) diklorometan-etil asetat (8:2) hareketli fazı ile Fr1-4 olarak isimlendirilen dört fraksiyon elde edildi. Illk iki fraksiyon ayrılarak üçüncü fraksiyon Fr3 (12.3 gr) için diklorometil-etil asetat ile iki farklı oranda (8:2 ve 6:4) hareketli fazlar oluşturuldu ve kolon kromatografisi ile silika jelde (150 gr, Merck, 230-400 mesh, ABD) ayrıştırıldı. Bu işlemden iki majör madde elde edildi ve kodlandı. Yapılan spektral analizlerde "ZY-1" olarak kodlanan maddenin OEA (4.8 gr) olduğu tespit edildi. Elde edilen OEA'ya ait spektral analiz bilgileri aşağıda verilmiştir. 
Oleanolik asit (ZY-1): beyaz amorf. IR $v_{\max }$ (ATR): $3393 \mathrm{~cm}^{-1}$ (br. $\left.-\mathrm{OH}\right), 2800-3000 \mathrm{~cm}^{-1}$ (güçlü $-\mathrm{CH}$ ), $1687 \mathrm{~cm}^{-1}(\mathrm{C}=\mathrm{O}), 1028 \mathrm{~cm}^{-1}(\mathrm{C}-\mathrm{O}) .{ }^{1} \mathrm{H}-\mathrm{NMR}(\delta, \mathrm{ppm})$ (DMSO-d $)_{6}$ ): $5.23(t, J=2.88,3.12 \mathrm{~Hz}, \mathrm{H}-12) ; 3.14(d d$, $\left.J_{1}=7.58 \mathrm{~Hz}, J_{2}=6.50,6.40 \mathrm{~Hz}, \mathrm{H}-3\right) ; 2.84\left(d d, J_{1}=13.74\right.$ $\mathrm{Hz}, J=3.96,3.84 \mathrm{~Hz}, \mathrm{H}-18) ; 2.01(t d, J=10.66 \mathrm{~Hz}$, $J=2.92,2.36 \mathrm{~Hz}, \mathrm{H}-2) ; 1.82(m, \mathrm{H}-11) ; 1.60(t, J=8.80$ $\mathrm{Hz}, \mathrm{H}-9) ; 1.41(m, \mathrm{H}-6) .{ }^{13} \mathrm{C}$ NMR $(\delta, \mathrm{ppm})\left(\mathrm{DMSO}_{-} \mathrm{d}_{6}\right)$ : 179.9 (28); 144.0 (13); 122.5 (12); 78.5 (3); 55.6 (5); 47.6 (9); 46.1 (19); 46.5 (17); 41.7 (14), 41.6 (18); 22.9 (16); 38.8 (4); 37.2 (10); 39.4 (8); 33.7 (21), 32.4 (29, 22); 32.6 (7); 30.4 (20); 27.6 (23); 28.1 (15); 27.8 (1); 26.7 (27); 23.3 (11), 22.8 (30); 26.5 (2); 18.3 (6); 16.7 (26); 14.8 (24); 15.4 (25).

\section{Hayvan modeli}

Bu çalışma için gerekli izin Atatürk Üniversitesi Deney Hayvanları Yerel Etik Kurulu'ndan alınmıştır (Toplantı No:13, Karar no: 164). Deneyde 30 adet erkek Wistar Albino cinsi rat (220-250 gr) sham, sepsis, OEA-150, OEA-300 ve CEFT olarak 5 eşit gruba ayrıldı. Çalışma öncesinde ratlar $12 / 12$ saatlik aydınlık/karanlık, $25^{\circ} \mathrm{C}$ oda sıcaklığı, ad libitum yem ve su olan standart şartlarda 1 hafta bekletildi. Çalışmada kullanılan OEA'nın dozu daha önce Singh ve ark. (1992) tarafından bildirilen anti-inflamatuvar etkinin gözlendiği değerler dikkate alınarak belirlendi. OEA 150 ve $300 \mathrm{mg} / \mathrm{kg}$ dozlarda su içinde süspanse edilerek oral olarak, referans olarak kullanılan seftriakson (CEFT) ise $150 \mathrm{mg} / \mathrm{kg}$ dozda hazırlanarak intraperitonal olarak CLP uygulamasından 15 dakika önce verildi. Çalışmada uygulanan CLP modeli daha önce Cadirci ve ark. (2010) tarafından bildirilen metoda uygun olarak yapıldı. Anestezi olarak ksilazin-ketamin uygulamasından sonra CLP sağ abdomen bölgesinden yapılan ensizyon ile gerçekleştirildi. Ensizyon hattından dışarı çıkarılan sekum 20-gaujluk bir kanül ile karşııklı olarak dört adet olacak şekilde delinerek perfore edildi. Ortalama apendiksten $1 \mathrm{~cm}$ aşağıdan 2-0 ipek iplik kullanılarak ligatüre edildi ve parmak ucuyla bir miktar sıkılarak feçesin dışarı çıkarak etrafına yayılması sağlandı. Tekrar abdomen içine yerleştirilerek 2-0 katküt kullanılarak süture edildi. Uygulamadan 24 saat sonra ratlar yüksek doz ksilazin-ketamin anestezisi (7,5 mg/kg ksilazin, $100 \mathrm{mg} /$ kg ketamin) altında servikal dislokasyon uygulanarak ötenazi edildi. Serum için kardiak punktur ile 5 ml'lik steril enjektöre alınan kan kırmızı kapaklı serum tüpüne konularak $+4^{\circ} \mathrm{C} 7$ dakika 3500 rpm'de santrifüj edildi. Serumlar eppendorf tüplere alınarak deney gününe kadar $-20^{\circ} \mathrm{C}$ derin dondurucuda saklandı. Daha sonra kalp dokusu histopatoloji için $\% 10^{\prime}$ luk formalin solüsyonu içerisine, biyokimyasal parametreler için ise steril petri kabına alındı. Petri kapları deney gününe kadar $-20^{\circ} \mathrm{C}$ 'de saklandı.

\section{Doku homojenatlarının hazırlanması}

Petri kabına alınan dokular sıvı nitrojen ile porselen bir havan yardımıyla toz haline getirildi. Daha sonra $25 \mathrm{mg}$ olarak steril eppendorf tüplerine tartılarak üzerlerine parametreye uygun olan homojenat

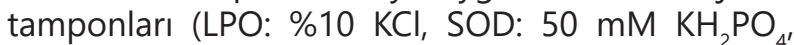
10 mM EDTA, GSH: $50 \mathrm{mM}$ Tris-HCl ve KAT: $50 \mathrm{mM}$ $\mathrm{KH}_{2} \mathrm{PO}_{4^{\prime}} \mathrm{pH}$ 7) eklendi. Tampon içindeki dokular 5 $\mathrm{mm}$ çelik bilye ile bir doku homojenizatörü (Qiagen Tissuelyser II, Almanya) kullanılarak $35 \mathrm{~Hz}$ frekansta 1 dakika boyunca homojenize edildi. Daha sonra homojenatlar soğutmalı santrifüjde (Hettich Rotina $320 \mathrm{R}$, Almanya) $+4^{\circ} \mathrm{C}^{\prime}$ de LPO ve GSH için $4000 \mathrm{rpm}$ 30 dakika, SOD için $6000 \mathrm{rpm} 1$ saat ve KAT için 8500 rpm 1 saat olarak santrifüj edildi. Elde edilen süpernatantlar daha sonra ölçüm metotlarına uygun şekilde kullanıldı.

\section{Doku lipit peroksidasyonu ve glutatyon seviyeleri ile süperoksit dismutaz ve katalaz aktivitelerinin belirlenmesi}

Doku LPO seviyesinin belirlenmesi için tiyobarbitürik asit ile malondialdehit arasında bir reaksiyonu temel alan, Ohkawa ve ark. (1979) tarafından tanımlanan metot kullanıldı. Doku LPO seviyesinin hesaplanmasında spektrofotometre (Bio-Tek EPOCH, ABD) ile 532 nm'de okunan absorbanslar 1,1,3,3-tetraethoksipropan ile oluşturulan standart grafik kullanılarak hesaplandı ve sonuçlar nmol MDA/gr doku olarak ifade edildi.

Doku SOD aktivitesinin belirlenmesinde için daha önce Sun ve ark. (1988) tarafından tanımlanan, ksantin oksidaz aktivitesi ile meydana gelen süperoksit radikallerinin oluşturduğu formazan boyasının belirlenmesine dayanan bir metot kullanıldı. Aktivitenin belirlenmesi için 560 nm'de okunan absorbanslar metotta belirtilen formülasyonla hesaplanarak U/mg doku olarak ifade edildi.

Doku GSH seviyesinin tespitinde Sedlak ve Lindsay (1968) tarafından tarif edilen, 5,5-ditiyo-bis-(2-nitrobenzoik asit) ile GSH'ın sülfidril grubu arasında meydana gelen reaksiyona dayanan bir metottan faydalanıldı. Deney sonunda $412 \mathrm{~nm}$ 'de okunan absorbanslar ile indirgenmiş GSH ile hazırlanan standart grafik kullanılarak sonuçlar hesaplanarak $\mathrm{nmol} / \mathrm{mg}$ doku olarak ifade edildi.

Doku KAT aktivitesi $\mathrm{H}_{2} \mathrm{O}_{2}$ 'in enzimatik bir reaksiyonla suya dönüşümünden faydalanılan ve Aebi (1984) tarafından tarif edilen metot kullanılarak be- 
lirlendi. Örnekler 240 nm'de kinetik olarak okunduktan sonra metotta belirtilen formül ile hesaplanarak $\mu \mathrm{mol} / \mathrm{min} / \mathrm{mg}$ doku olarak ifade edildi.

\section{Serum kreatin kinaz-MB ve laktat dehidrojenaz aktivitesinin belirlenmesi}

Serum kreatin kinaz (CK-MB) ve laktat dehidrogenaz (LDH) aktivitelerinin belirlenmesinde ticari kitler (Erba Lachema XL SysPack, Çekya) kullanıldı ve analizler kit ile beraberinle gelen prosedür talimatlarına uygun olarak gerçekleştirildi. Sonuçlar normal, patolojik ve multi standart serumları (ERBA Norm, ERBA Path, ERBA Multi, Çekya) ile hazırlanan standart grafik kullanılarak hesaplandı ve U/L olarak ifade edildi.

\section{Histopatolojik olarak dokuların hazırlanması ve incelenmesi}

Nekropsiden elde edilen kalp dokusu \%10'luk formalin solüsyonunda 48 saat fikse edildikten sonra taze su ile 10 saat yıkandı. Dokular parafin bloklara gömüldü ve her bloktan $4 \mu \mathrm{m}$ kalınlığında kesitler alındı. Hematoksilen-eozin ile boyanan preparatlar bir ışık mikroskobu altında incelendi. Patolojik bulgular (miyokartta hyalin dejenerasyonu, Zenker nekrozu ve damarlarda hiperemi) derecesine göre yok $(-)$, hafif $(+)$, orta $(++)$ ve şiddetli $(+++)$ olarak skorlanarak doku hasar seviyesi belirlendi.

\section{Immünohistokimyasal analiz ve ekspresyonun belirlenmesi}

Histopatolojik analiz için hazırlanmış olan preperatlar immünoperoksidaz inceleme için artan alkol konsantrasyonlarından geçirilerek ksilol ile dokudaki su uzaklaştırıldı. Endojen peroksidaz inaktivasyonu için PBS banyosu sonrası 10 dakika \%3'lük $\mathrm{H}_{2} \mathrm{O}_{2}$ solüsyonunda inkübe edildi. Bu yıkama ve inkübasyon işlemleri iki defa tekrarlandıktan sonra antijenleri tespit eden retrieval solüsyonu ile iki defa tekrarlı 500 watt mikro dalga uygulaması yapıldı. Soğutulduktan sonra örnekler TNF- $\alpha$ (sc-52746, Santa Cruz, ABD) ve IL-1 $\beta$ (sc-52012, Santa Cruz, ABD) antikorları ile immunohistokimya kit (ab64264, Abcam HRP/DAB Detection IHC kit) prosedüründe tarif edilen şekilde $37^{\circ} \mathrm{C}$ 'de 1 saat inkübe edildi. Kromojen olarak kit ile temin edilen 3-3' Diaminobenzidine (DAB) kullanıldı. Zemin hematoksilen ile boyanarak kesitler immünpozitifliklerine göre yok $(-)$, hafif $(+)$, orta $(++)$ ve şiddetli $(+++)$ olarak değerlendirildi.

\section{istatistiksel Analiz}

Elde edilen biyokimyasal parametreler Prism 8.0 yazılımı kullanılarak analiz edildi. Grupların kıyas- lanmasında ANOVA (Tek yönlü varyans analizi) kullanılarak çoklu grup kıyaslaması için Tukey testi gerçekleştirildi. Yapılan analizlerde $\mathrm{P}<0.05$ değeri anlamlı, $P<0.01$ değeri çok anlamlı, $P<0.001$ değeri ise yüksek derecede anlamlı olarak değerlendirildi. Histopatolojik ve immünohistokimyasal parametrelerin değerlendirilmesinde semikantitatif olarak elde edilen verilerin gruplar arasındaki farklılıkların analizi için non-parametrik testlerden Kruskal-Wallis testi, ikili grupların mukayesesi için Mann Whitney $U$ testi kullanıldı. Bu istatistik analizleri için SPSS 13.0 paket programı kullanıldı.

\section{Bulgular}

\section{Doku lipit peroksidasyon seviyesi}

Doku LPO seviyesinin sepsis grubunda (526.2 \pm 25.98$)$ sham grubu $(314.0 \pm 17.70)$ ile kıyaslandığında CLP uygulaması ile önemli derecede arttığı tespit edildi $(P<0.001)$. Tedavi olarak uygulanan CEFT (428.2 \pm 18.58$)(P<0.001)$, OEA-150 (363.4 \pm 22.65$)$ ve OEA-300 $(352.8 \pm 21.53)(P<0.05)$ gruplarında düşüş tespit edildi $(\mathrm{P}<0.001)($ Şekil $1 \mathrm{~A})$.

\section{Doku süperoksit dismutaz aktivitesi}

Doku SOD aktivitesi sham grubu (34.05 \pm 0.42$)$ ile kıyaslandığında sepsis grubunda $(30.70 \pm 0.61)$ düştüğü tespit edildi $(\mathrm{P}<0.001)$. Tedavi olarak uygulanan CEFT (34.08 \pm 0.14$)$, OEA-150 (33.05 \pm 0.22$)$ ve OEA-300 (33.93 \pm 0.49$)$ gruplarında sepsis grubu ile kıyaslandığında azalan aktivitenin arttığı belirlendi $(P<0.001)$ (Şekil 1B).

\section{Doku glutatyon seviyesi}

Doku GSH seviyesinin sham grubuna $(5.21 \pm 0.17)$ kıyasla sepsis grubunda (7.46 \pm 0.39$)$ arttığı tespit edildi $(P<0.001)$. Tedavi olarak uygulanan OEA-150 $(6.43 \pm 0.27)$ ve OEA-300 (6.25 \pm 0.38$)$ artan bu seviyeyi düşürse de $(P<0.001)$ CEFT $(7.24 \pm 0.28)$ grubundaki azalma istatistiksel olarak önemli değildi $(P>0.05)$ (Şekil 1C).

\section{Doku katalaz aktivitesi}

Doku KAT aktivitesi sham grubu (498.5 \pm 25.51$)$ ile kıyaslandığında sepsis grubunun $(634.5 \pm 53.64)$ aktivitesinde artış tespit edildi $(P<0.05)$. Tedavi olarak uygulanan CEFT $(465.3 \pm 47.50)$ ve OEA-300 (492.9 \pm 44.36$)$ gruplarında artan bu aktivite önemli seviyede düştüğü belirlendi $(P<0.01)$. Fakat OEA-

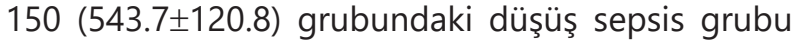
(634.5 \pm 53.64$)$ ile kıyaslandığında anlamlı bulunmadı (P>0.05) (Şekil 1D). 
A Kalp Dokusu LPO Seviyesi

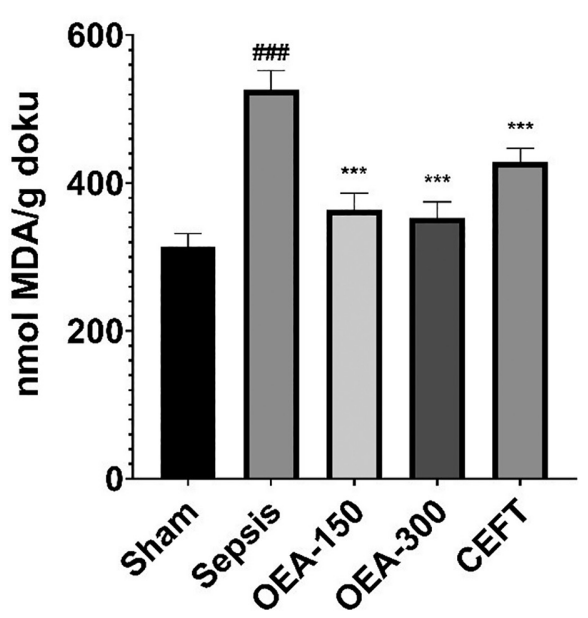

C Kalp Dokusu GSH Seviyesi

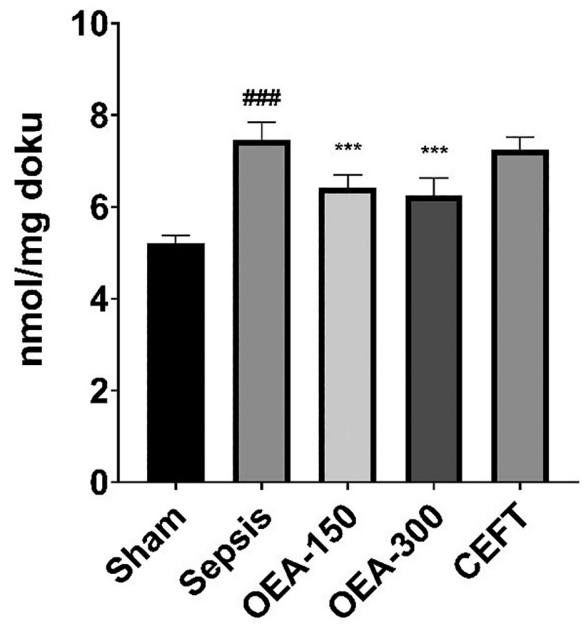

B Kalp Dokusu SOD Aktivitesi

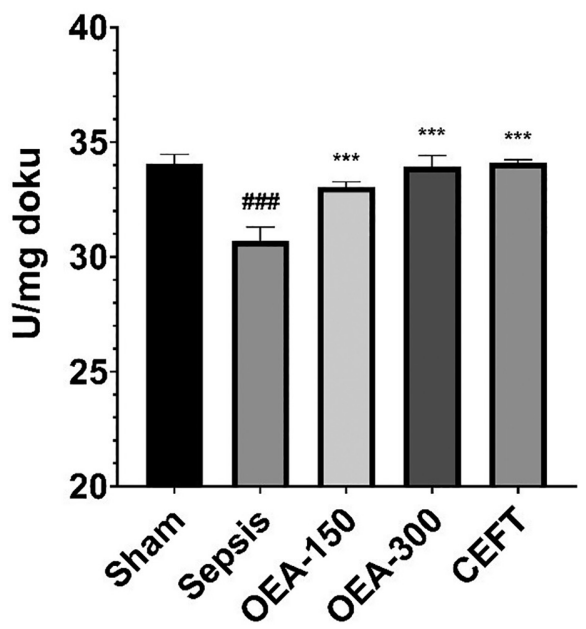

D Kalp Dokusu KAT Aktivitesi

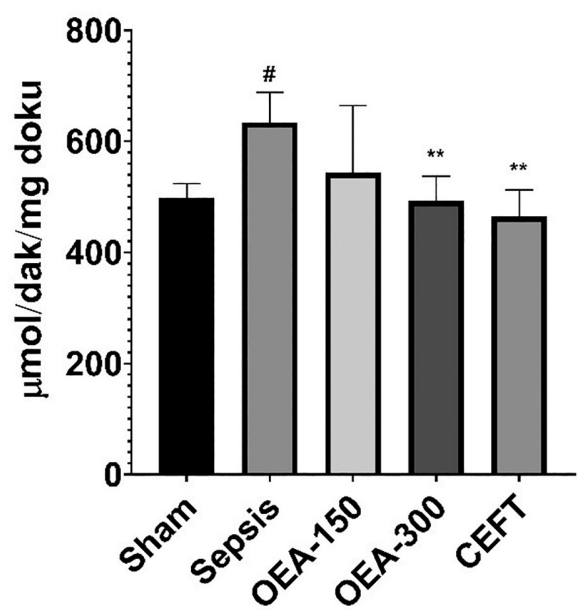

Şekil 1. Kalp dokusu antioksidan parametreleri. Kalp dokusu LPO seviyesi A, Kalp dokusu SOD aktivitesi B, Kalp dokusu GSH seviyesi C, Kalp dokusu KAT aktivitesi D.

OEA: Oleanolik asit, CEFT: Seftriakson. "Sham vs Sepsis, $\mathrm{P}<0.05$; \#"Sham vs Sepsis, $\mathrm{P}<0.01$; \#\#"Sham vs Sepsis, $\mathrm{P}>0.001$. "Sepsis vs Tedavi, $\mathrm{P}<0.05 ;{ }^{* *}$ Sepsis vs Tedavi, $\mathrm{P}<0.01 ;{ }^{* *}$ Sepsis vs Tedavi, $\mathrm{P}<0.001$.

\section{Serum kreatin kinaz ve laktat dehidrojenaz aktiviteleri}

Şekil $2 \mathrm{~A}$ ve $2 \mathrm{~B}^{\prime}$ de gösterilen sepsis grubu serum CK-MB (224.5 \pm 28.5$)$ ve LDH (1112 \pm 175.0$)$ aktiviteleri sham grubu CK-MB (111.2 \pm 10.0$)$ ve LDH (330.3 \pm 98.9$)$ aktiviteleri ile kıyaslandığında artmıştır $(\mathrm{P}<0.001)$. Tedavi olarak uygulanan CEFT (CK-MB: 153.0 \pm 13.71 , LDH: 379.2 223.0 ), OEA-150 (CK-MB: 111.6 \pm 22.4 , LDH: $554.2 \pm 230.6$ ) ve OEA-300 (CK-MB: 127.5 \pm 23.21 , LDH: $551.8 \pm 233.6)$ artan bu aktiviteleri azalttığı belirlendi $(P<0.001)$.

\section{Kalp dokusunun histopatolojik incelemesi}

Kalp dokularının histopatolojik incelenmesinde, sham grubunda myokart, endokart ve perikart tabakalarının normal histolojik yapıda olduğu gözlendi (Şekil 3A). Sepsis grubunun myokartının kas liflerinde şiddetli düzeyde hyalin dejenerasyonu ve Zenker nekrozu gözlendi. Damarlarda şiddetli düzeyde hiperemi ve hemoraji belirlendi (Şekil 3B). OEA-150 grubunun damarlarında orta düzeyde hiperemi, kas liflerinde orta düzeyde hyalin dejenerasyonu ve zenker nekrozu olduğu belirlendi (Şekil 3C). OEA-300 
grubunun kas liflerinde hafif düzeyde hyalin dejenerasyonu ve damarlarda hiperemi olduğu gözlendi (Şekil 3D). CEFT grubunun kas liflerinde hafif düzey-

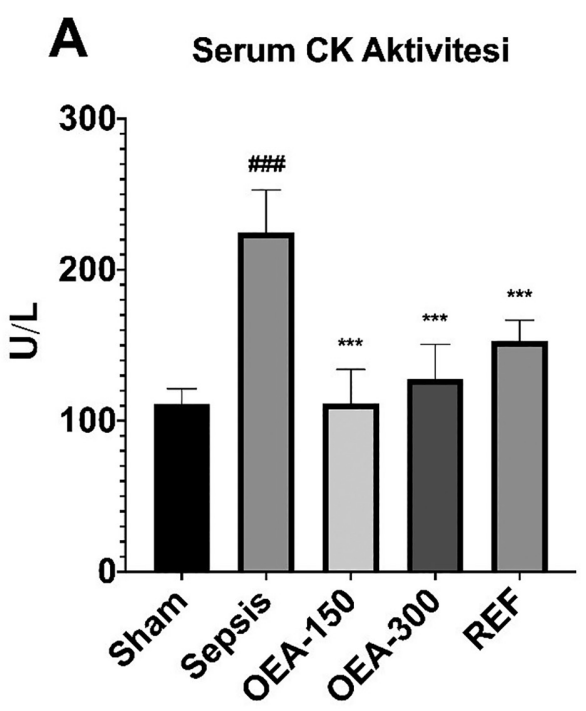

de dejenerasyon, Zenker nekrozu ve damarlarda hiperemi belirlendi (Şekil 3E). Tüm histopatolojik bulgular Tablo 1 ile özetlendi.

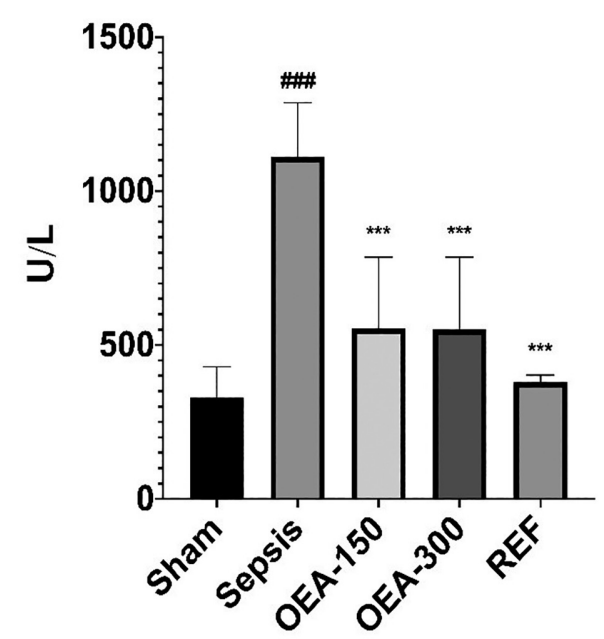

Şekil 2. Serum CK-MB ve LDH aktiviteleri

OEA: Oleanolik asit, CEFT: Seftriakson. \#Sham vs Sepsis, $\mathrm{P}<0.05$; \#\#Sham vs Sepsis, $\mathrm{P}<0.01$; \#\#\#Sham vs Sepsis, $\mathrm{P}>0.001$. "Sepsis vs Tedavi, $\mathrm{P}<0.05$; ${ }^{* *}$ Sepsis vs Tedavi, $\mathrm{P}<0.01 ;{ }^{* * *}$ Sepsis vs Tedavi, $\mathrm{P}<0.001$.

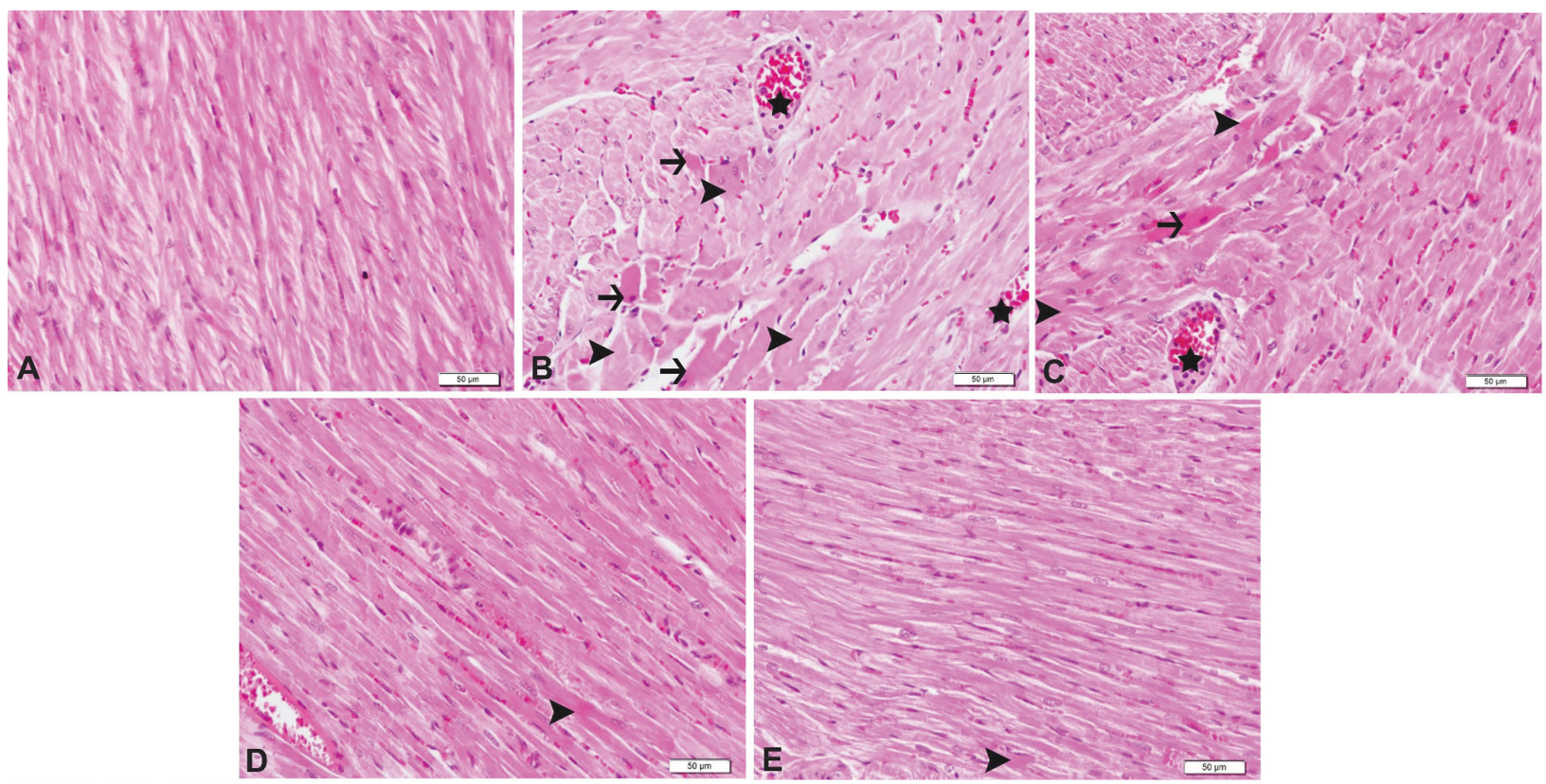

Şekil 3. Kalp dokusu, sham grubu, normal histolojik görünüm (A), sepsis grubu, şiddetli düzeyde kas liflerinde hyalin dejenerasyonu (ok başları), Zenker nekrozu (ince oklar), damarlarda hiperemi (yıldızlar) (B), OEA-150 grubu, orta düzeyde kas liflerinde hyalin dejenerasyonu (ok başları), zenker nekrozu (ince ok), damarlarda hiperemi (yıldız) (C), OEA-300 grubu, hafif düzeyde kas liflerinde hyalin dejenerasyonu (ok başları), , damarlarda hiperemi (D), CEFT grubu, hafif düzeyde kas liflerinde hyalin dejenerasyonu (ok

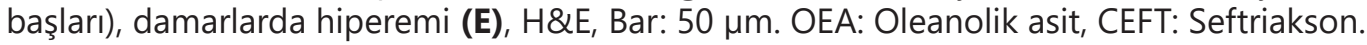




\section{Kalp dokusunun immünohistokimyasal incelemesi}

Kalp dokularının immunohistokimyasal olarak incelemesinde, sham grubunda negatif TNF- $\alpha$ ve IL-1 $\beta$ ekspresyonu belirlendi (Şekil 4A, 5A). Kontrol grubu, şiddetli düzeyde hasarlı bölgelerde mononükleer hücrelerde ve perivasküler yerleşimli TNF- $\alpha$ ekspresyonu, myokartında interstisyel aralıklarda ve perivasküler yerleşimli şiddetli düzeyde IL-1 $\beta$ ekspresyonu tespit edildi (Şekil 4B, 5B). OEA-150 grubunda orta şiddette hasarlı bölgelerde mononükleer hücrelerde ve perivasküler yerleşimli TNF- $\alpha$ ekspresyonu, interstisyel aralıklarda ve perivasküler IL-1 $\beta$ ekspresyonu gözlendi (Şekil 4C, 5C). OEA-300 grubunda hasarlı bölgelerde hafif düzeyde mononükleer hücrelerde ve perivasküler yerleşimli TNF- $\alpha$ ekspresyonu, interstisyel aralıklarda ve perivasküler yerleşimli hafif düzeyde IL-1 $\beta$ ekspresyonu belirlendi (Şekil 4D, 5D). CEFT grubunda hafif düzeyde perivasküler yerleşimli TNF- $\alpha$ ve IL-1 $\beta$ ekspresyonu belirlendi (Şekil 4E, 5E). Gruplara ait immünohistokimyasal bulgular Tablo 1 ile özetlendi.

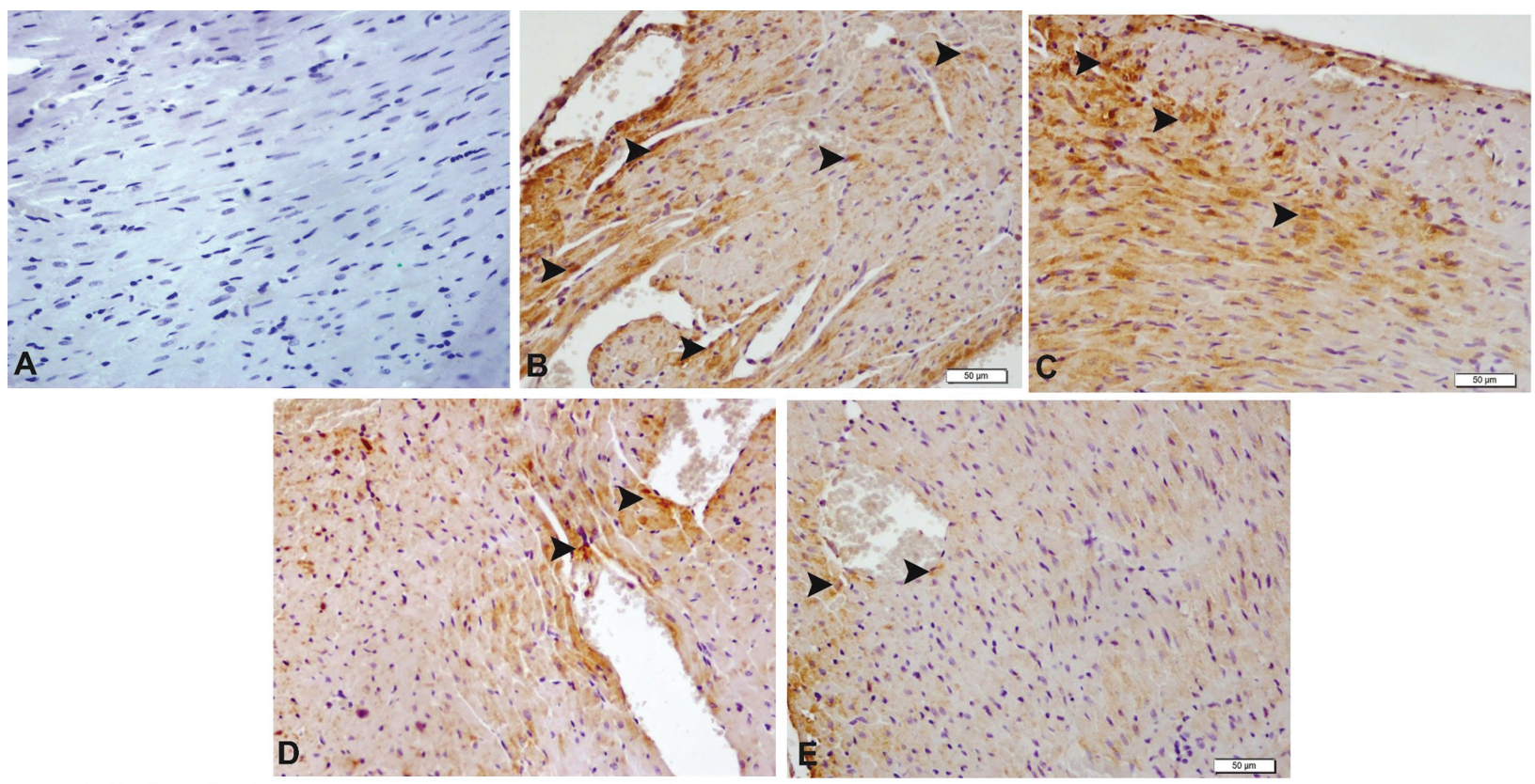

Şekil 4. Kalp dokusu, sham grubu, negatif TNF- $\alpha$ ekspresyonu (A), sepsis grubu, şiddetli düzeyde hasarlı bölgelerde mononükleer hücrelerde ve perivasküler TNF- $\alpha$ ekspresyonu (ok başları) (B), OEA-150 grubu, orta düzeyde mononükleer hücrelerde ve perivasküler TNF- $\alpha$ ekspresyonu (ok başları) (C), OEA-300 grubu, hafif düzeyde perivasküler TNF- $\alpha$ ekspresyonu (ok başları) (D), CEFT grubu, hafif düzeyde perivasküler

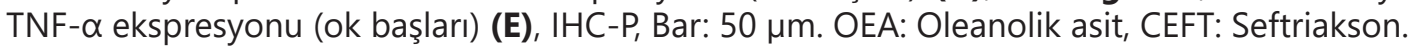

Tablo 1. Kalp dokusu histopatolojik ve immünohistokimyasal bulguların skorlanması

\begin{tabular}{|c|c|c|c|c|c|}
\hline & Sham & Sepsis & OEA-150 & OEA-300 & CEFT \\
\hline Miyokartta hyalin dejenerasyonu & - & +++ & +++ & + & ++ \\
\hline Miyokartta zenker nekrozu & - & +++ & ++ & + & + \\
\hline Damarlarda hiperemi & - & +++ & +++ & ++ & ++ \\
\hline TNF- $\alpha$ & - & +++ & ++ & + & + \\
\hline IL-1 $\beta$ & - & +++ & ++ & + & + \\
\hline
\end{tabular}

OEA: Oleanolik asit, CEFT: Seftriakson, TNF- $\alpha$ : Tümör nekrozis faktör-alfa, IL-1ß: Interlökin -1Beta. 


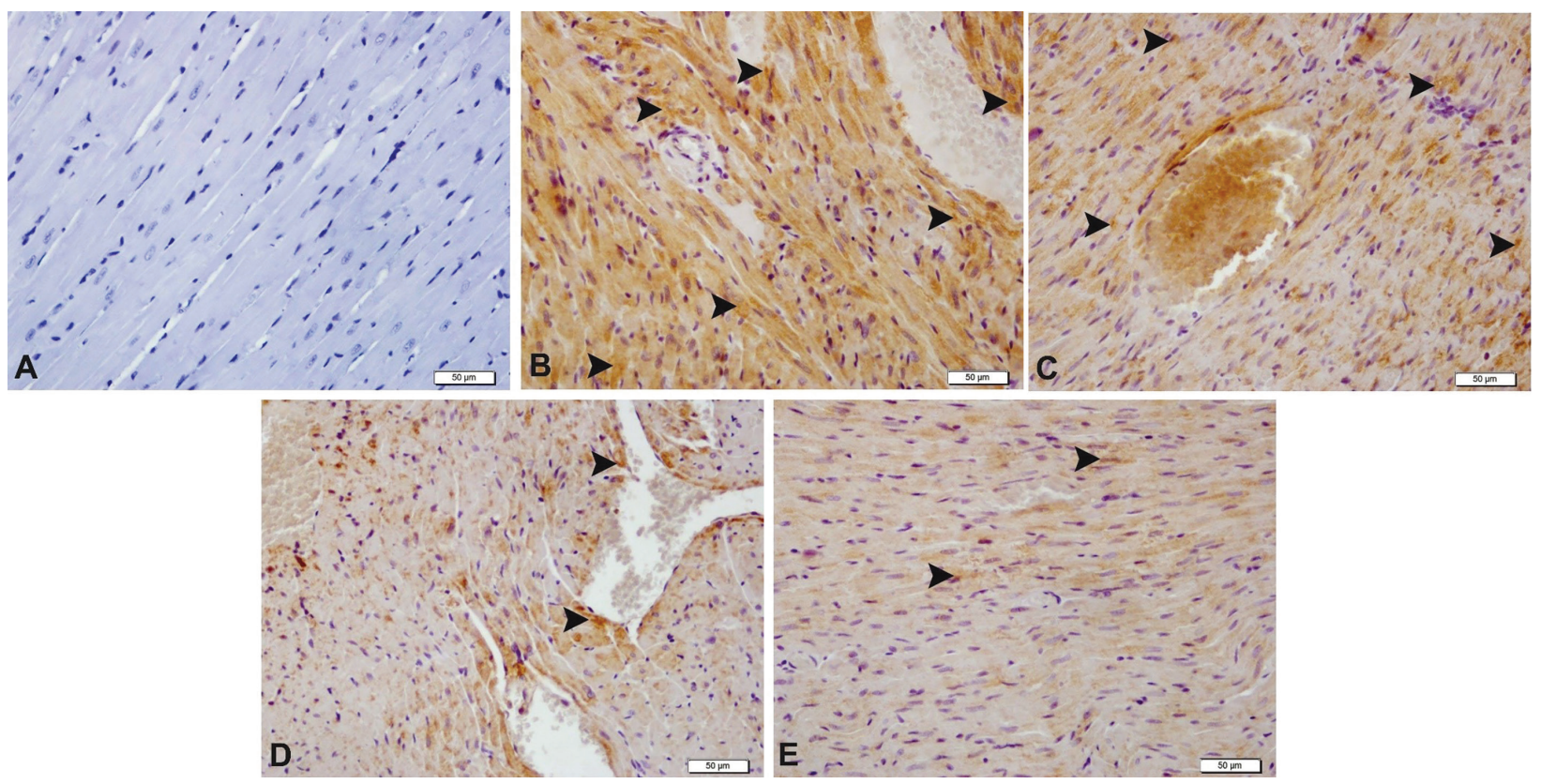

Şekil 5. Kalp dokusu, sham grubu, negatif IL-1ß ekspresyonu (A), sepsis grubu, interstisyel aralıklarda ve perivasküler IL-1 $\beta$ ekspresyonu (ok başları) (B), OEA-150 grubu, orta düzeyde interstisyel aralıklarda ve perivasküler IL-1 $\beta$ ekspresyonu (ok başları) (C), OEA-300 grubu, hafif düzeyde perivasküler IL-1 $\beta$ ekspresyonu (ok başları) (D), CEFT grubu, hafif düzeyde perivasküler IL-1 $\beta$ ekspresyonu (ok başları) (E), IHC-P, Bar: 50 $\mu \mathrm{m}$. OEA: Oleanolik asit, CEFT: Seftriakson.

\section{Tartışma ve Sonuç}

Sepsis sırasında meydana gelen oksidatif stres sonucunda üretilen ROS'ler hücrenin hayati yapıları olan membran doymamış yağ asitleri ve proteinlere saldırır. Membranda meydana gelen oksidatif hasar sonucunda malondialdehit (MDA) ve diğer oksidasyon ürünleri ortaya çıkmaktadır. Dokudaki MDA miktarı o dokunun LPO seviyesini göstermektedir (Erol ve ark. 2019). Doksorobisin ile indüklenen kalp hasarı üzerine yapılan bir çalışmada OEA'in doku MDA miktarını azalttığını, uygulama ile azalan SOD ve KAT aktivitelerinin yanı sıra GSH miktarını da arttırdığı bildirilmiştir (Goyal ve ark. 2016). Diğer yandan izoproterenol ile indüklenmiş myokardial iskemi modeli üzerine yapılan bir çalışmada OEA'in artan MDA miktarını azalttığı ve güçlü kardiyoprotektif etkilere sahip olduğu gösterilmiştir (Senthil ve ark. 2007). Çalışmada daha önceki çalışmalara paralel şekilde OEA'in kalp doku MDA miktarını düşürerek doku LPO seviyesini azalttığı tespit edilmiştir. Daha önceki çalışmalar OEA'in Vitamin E benzeri süpürücü etkiye sahip olduğunu ve hücrelerde oksidanlara karşı savunmayı başlatan Nrf2'yi aktive ederek antioksidan aktivite gösterdiği bildirilmiştir (MarquezMartin ve ark. 2006; Reisman ve ark. 2009). Bu çalışmada OEA'in serbest radikal miktarını azaltarak ve antioksidan savunmayı güçlendirerek LPO seviyesinde azalmayı sağladığı düşünülmektedir.

Hücrelerde antioksidan sistemin önemli üyelerinden biri SOD'dir. Bu enzim ROS'ler üzerinde bulunan eşleşmemiş elektronu suya aktararak hidrojen peroksit oluşturur (Erol ve ark. 2019). Sepsis hücrelerde lizozamal hidrolitik enzim kaçaklarına ve yaygın doku hasarına sebep olur. Bu durumun sepsiste meydana gelen SOD aktivitesindeki azalmanın sebebi olduğu bildirilmektedir (Rocha ve ark. 2012). Çalışmada doku hasarını gösteren patolojik bulgulara paralel olarak sepsis uygulaması ile belirgin bir şekilde azalan doku SOD aktivitesinin OEA uygulaması ile önemli seviyede arttığı belirlenmiştir.

Antioksidan sistemin diğer önemli bir üyesi de bir tripeptit olan GSH'dır. Hücrede GSH, glutatyon peroksidaz (GPx) tarafından bir substrat olarak kullanılır ve SOD tarafından oluşturulan $\mathrm{H}_{2} \mathrm{O}_{2}$ 'in suya dönüşümünde görev alır (Erol ve ark. 2019). Daha önce ratlarda CLP ile indüklenen sepsis modeli üzerine yapılmış çalışmalarda kalp GSH seviyesindeki değişimin istatistiksel olarak anlamlı olmadığı rapor edilmiştir (Coskun ve ark. 2011; Dadkhah ve Fatemi 2011). Ancak, sepsiste glutatyon metabolizması üzerine yapılmış diğer bir çalışmada, sepsisin yoğun proinflamatuvar sitokinlerin (TNF- $\alpha$ ve IL-1 $\beta$ ) üreti- 
mine, ve ayrıca bu sitokinlerin GSH sentezini arttırarak hücrede yüksek GSH seviyesine neden olduğu rapor edilmiştir (Biolo ve ark. 2007). Diğer taraftan, çalışmada kalp doku GSH seviyesinin sepsis grubunun immünohistokimyasal analizlerinde gözlenen sitokin seviyelerindeki artışla beraber belirgin şekilde arttığı belirlenmiştir. Ayrıca OEA'nin sitokin seviyeleriyle beraber GSH seviyesinde de azalma sağladığı tespit edilmiştir.

Hücrede SOD tarafından üretilen $\mathrm{H}_{2} \mathrm{O}_{2}$ 'in suya dönüştürülmesini katalizleyen bir diğer önemli yapıda KAT enzimidir. Ratlarda CLP ile indüklenen sepsis üzerine yapılan bir çalışmada sepsisin kalp doku KAT aktivitesini önemli derecede arttırdığı bildirilmiştir (Petronilho ve ark. 2016). Ayrıca sepsis şiddetinin antioksidan sistem üzerine etkisinin araştırıldığı bir çalışmada hastalığın şiddetinin artmasıyla SOD/KAT oranında dengesizlik meydana geldiği ve bu durumun özellikle kalp dokusunda şekillendiği bildirilmiştir (Andrades ve ark. 2005). Benzer şekilde mevcut çalışmada kalp KAT aktivitesi CLP uygulamasıyla birlikte belirgin şekilde artarken OEA'in sadece 300 $\mathrm{mg} / \mathrm{kg}$ dozda artan bu aktiviteyi anlamlı şekilde düşürdüğü belirlenmiştir. SOD ve KAT aktivitelerinde bir oranlama yapılmamış olsa da sepsis sonucunda kalpte meydana gelen SOD aktivitesindeki düşüş ile KAT aktivitesindeki artışın bu dengesizliğin bir sonucu olarak şekillendiği düşünülmektedir.

Sepsis ile meydana gelen kalp dokusu hasarında serum CK-MB ve LDH aktiviteleri önemli derecede arttığı daha önceki çalışmalarda bildirilmiştir (Zhou ve ark. 2015; Ozer ve ark. 2017). Ratlarda doksorobisin ile indüklenen kardiak toksite üzerine yapılan bir çalışmada serum CK-MB ve LDH aktivitelerinin belirgin şekilde arttığı, OEA'in ise artan bu aktiviteleri önemli derecede azalttığı rapor edilmiştir (Goyal ve ark. 2016). Önceki çalışmalara paralel olarak, mevcut çalışmada da sepsis grubunda serum CK-MB ve $L D H$ aktiviteleri beklenen şekilde anlamlı derecede artmıştır. Bu artışların çalışmanın histopatolojik incelemesinde gözlenen sepsis tarafından oluşturulan doku hasarına bağlı olarak şekillendiği düşünülmektedir.

İnflamasyon sürecinin başlangıcında salgılanan TNF- $\alpha$ diğer sitokinlerin salgılanmasını uyararak pro-inflamatuvar bir görev görür (Marquez-Martin ve ark. 2006). Daha sonra TNF- $\alpha$ 'ya cevap olarak makrofaj, monosit ve nötrofillerden salınımı uyarılan IL-1 $\beta$ kalp kontraksiyonlarını baskılayan iNOS üretimini tetikler (Drosatos ve ark. 2015). Daha önceki çalışmalarda, OEA'in, TNF- $\alpha$, IL-1 $\beta$, IL- 6 ve MafK ekspresyonlarını baskılamasıyla NF-kB'nin üretimindeki azalmanın anti-inflamatuvar özelliğinin temelini oluşturduğu bildirilmiştir (Marquez-Martin ve ark. 2006; Lee ve ark. 2013; Hwang ve ark. 2014). Diğer yandan daha önce lipopolisakkarit (LPS) ile nitrik oksit üretimi indüklenen RAW 264.7 makrofaj hücreleri üzerine yapılan bir çalışmada OEA'in güçlü bir anti-inflamatuvar molekül olarak bilinen indometazinden daha güçlü anti-inflamatuvar etki gösterdiği bildirilmiştir (Huang ve ark. 2016). Çalışmanın immünohistokimyasal sonuçlarında daha önceki çalışmalara paralel olarak OEA'in kalp dokusu TNF- $\alpha$ ve IL-1 $\beta$ ekspresyonunu azalttığı ve bu şekilde anti-inflamatuvar etki gösterdiği gözlenmiştir. Diğer yandan histopatolojik incelemede kalp dokusu myokartta kas liflerinde şiddetli düzeyde hyalin dejenerasyonu, Zenker nekrozu, damarlarda şiddetli düzeyde hiperemi ve hemoraji belirlendi. Sitokin salınımını ile artan inflamatuvar yanıtın kalp dokusunda hiperemi, nekroz ve dejenerasyona sebep olduğu daha önceki çalışmalarda da bildirilmiştir (Yun ve ark. 2009; Zhang ve ark. 2017; Erol ve ark. 2020).

Sonuç olarak çalışmanın bulguları göz önüne alındığında OEA uygulamasının CLP ile indüklenen sepsis modelinde kalp dokusu hasarını azalttığı ve oksidatif hasarı engellediği tespit edilmiştir. OEA bu etkiyi kalp dokusu TNF- $\alpha$ ve IL- $1 \beta$ sitokinlerinin üretimini baskılamasının yanı sıra, SOD, KAT ve GSH gibi antioksidan parametrelerinde düzelmeler gerçekleştirerek sağlamıştır. Böylece dokuda MDA seviyesi düşmüş ve histopatolojik bulguların şiddetinde azalma gözlenmiştir. Bu çalışmadan elde edilen bulgular ışığında OEA'in sepsiste meydana gelen kalp dokusu hasarının azaltılmasında faydalı olabileceği düşünülmektedir.

Deney hayvanları kullanımı etik kurulu ve diğer etik kurul kararları ve izinler: Atatürk Üniversitesi Hayvan Deneyleri Yerel Etik Kurulu tarafından 30.11.2017 tarihli 13 nolu toplantının 165 nolu kararı ile etik kurul izni alınmıştır.

\section{Kaynaklar}

Aebi H. (1984). Catalase in vitro. Methods Enzymol. 105, 121-126. Andrades M, Ritter C, Moreira JCF, Dal-Pizzol F. (2005). Oxidative Parameters Differences during Non-Lethal and Lethal Sepsis Development1. J Surg Res. 125, 68-72.

Baykara N, Akalın H, Arslantaş MK, Hancı V, Çağlayan Ç, Kahveci F, Demirağ K, Baydemir C, Ünal N, Özdemir P, Ulusoy H, Memiş D. (2018). Epidemiology of sepsis in intensive care units in Turkey: a multicenter, point-prevalence study. Crit Care. 22 93

Biolo G, Antonione R, De Cicco M. (2007). Glutathione metabolism in sepsis. Crit Care Med. 35, S591-S595.

Cadirci E, Altunkaynak BZ, Halici Z, Odabasoglu F, Uyanik MH, Gundogdu C, Suleyman H, Halici M, Albayrak M, Unal B. (2010). $\alpha$-lipoic acid as a potential target for the treatment 
of lung injury caused by cecal ligation and puncture-induced sepsis model in rats. Shock. 33, 479-484.

Chousterman BG, Swirski FK, Weber GF. (2017). Cytokine storm and sepsis disease pathogenesis. Semin Immunopathol. 39, 517-528.

Coskun AK, Yigiter M, Oral A, Odabasoglu F, Halici Z, Mentes O, Cadirci E, Atalay F, Suleyman H. (2011). The effects of Montelukast on antioxidant enzymes and proinflammatory cytokines on the heart, liver, lungs, and kidneys in a rat model of cecal ligation and puncture-induced sepsis. Sci World J. 11, 1341-1356.

Dadkhah A, Fatemi F. (2011). Heart and kidney oxidative stress status in septic rats treated with caraway extracts. Pharm Biol. 49, 679-686.

Drosatos K, Lymperopoulos A, Kennel PJ, Pollak N, Schulze PC Goldberg IJ. (2015). Pathophysiology of sepsis-related cardiac dysfunction: driven by inflammation, energy mismanagement, or both? Curr Heart Fail Rep. 12, 130-140.

Erol H, Aydın T, Yıldııım S, Can I, Halıcı M. (2020). The effects of oleuropein on lung and heart injury in cecal ligation and puncture - induced sepsis. Eurasian Journal of Veterinary Sciences. 36, 221-231.

Erol N, Saglam L, Saglam YS, Erol HS, Altun S, Aktas MS, Halici MB. (2019). The Protection Potential of Antioxidant Vitamins Against Acute Respiratory Distress Syndrome: a Rat Trial. Inflammation. 42, 1585-1594.

Goyal SN, Mahajan UB, Chandrayan G, Kumawat VS, Kamble S, Patil P, Agrawal YO, Patil CR, Ojha S. (2016). Protective effect of oleanolic acid on oxidative injury and cellular abnormalities in doxorubicin induced cardiac toxicity in rats. Am J Transl Res. 8, 60-69.

Huang J, Wang Y, Li C, Wang X, He X. (2016). Anti-inflammatory oleanolic triterpenes from Chinese Acorns. Molecules. 21, 669.

Hwang Y-J, Song J, Kim HR, Hwang KA. (2014). Oleanolic acid regulates NF-KB signaling by suppressing MafK expression in RAW 264.7 cells. BMB reports. 47, 524-529.

Kısa A, Akyüz M, Çoğun HY, Kordali \$, Bozhüyük AU, Tezel B, Şiltelioğlu U, Anıl B, Çakır A. (2018). Effects of Olea europaea L. leaf metabolites on the tilapia (Oreochromis niloticus) and three stored pests, Sitophilus granarius, Tribolium confusum and Acanthoscelides obtectus. Rec Nat Prod. 12, 201-215.

Lee H, Lee IS, Choue R. (2013). Obesity, inflammation and diet. Pediatr Gastroenterol Hepatol Nutr. 16, 143-152.

Liu J. (1995). Pharmacology of oleanolic acid and ursolic acid. J Ethnopharmacol. 49, 57-68.

Liu J. (2005). Oleanolic acid and ursolic acid: research perspectives. J Ethnopharmacol. 100, 92-94.

Marquez-Martin A, De La Puerta R, Fernandez-Arche A, RuizGutierrez V, Yaqoob P. (2006). Modulation of cytokine secreti- on by pentacyclic triterpenes from olive pomace oil in human mononuclear cells. Cytokine. 36, 211-217.

Ohkawa H, Ohishi N, Yagi K. (1979). Assay for lipid peroxides in animal tissues by thiobarbituric acid reaction. Anal Biochem. 95, 351-358.

Ozer EK, Goktas MT, Kilinc I, Pehlivan S, Bariskaner $\mathrm{H}$, Ugurluoglu C, Iskit AB. (2017). Coenzyme Q10 improves the survival, mesenteric perfusion, organs and vessel functions in septic rats. Biomed Pharmacother. 91, 912-919.

Petronilho F, Florentino D, Danielski LG, Vieira LC, Martins MM, Vieira A, Bonfante S, Goldim MP, Vuolo F. (2016). Alpha-lipoic acid attenuates oxidative damage in organs after sepsis. Inflammation. 39, 357-365.

Reisman SA, Aleksunes LM, Klaassen CD. (2009). Oleanolic acid activates Nrf2 and protects from acetaminophen hepatotoxicity via Nrf2-dependent and Nrf2-independent processes. Biochem Pharmacol. 77, 1273-1282.

Rocha M, Herance R, Rovira S, Hernández-Mijares A, Victor VM. (2012). Mitochondrial dysfunction and antioxidant therapy in sepsis. Infect Disord Drug Targets. 12, 161-78.

Sedlak J, Lindsay RH. (1968). Estimation of total, protein-bound, and nonprotein sulfhydryl groups in tissue with Ellman's reagent. Anal Biochem. 25, 192-205.

Senthil S, Sridevi M, Pugalendi K. (2007). Cardioprotective effect of oleanolic acid on isoproterenol-induced myocardial ischemia in rats. Toxicol Pathol. 35, 418-423.

Simmons J, Pittet JF. (2015). The coagulopathy of acute sepsis. Curr Opin Anaesthesiol. 28, 227-236.

Singh GB, Singh S, Bani S, Gupta BD, Banerjee SK. (1992). Antiinflammatory activity of oleanolic acid in rats and mice. $J$ Pharm Pharmacol. 44, 456-458.

Sun Y, Oberley LW, Li Y. (1988). A simple method for clinical assay of superoxide dismutase. Clin Chem. 34, 497-500.

Topçu G, Öztürk M, Kuşman T, Demirkoz AAB, Kolak U, Ulubelen A. (2013). Terpenoids, essential oil composition, fatty acid profile, and biological activities of Anatolian Salvia fruticosa Mill. Turk J Chem. 37, 619-632.

Winters BD, Eberlein $M$, Leung J, Needham DM, Pronovost PJ, Sevransky JE. (2010). Long-term mortality and quality of life in sepsis: a systematic review. Crit Care Med. 38, 1276-1283.

Yun N, Lee CH, Lee SM. (2009). Protective effect of Aloe vera on polymicrobial sepsis in mice. Food Chem Toxicol. 47, 13411348.

Zhang J, Bi J, Liu S, Pang Q, Zhang R, Wang S, Liu C. (2017). 5-HT Drives Mortality in Sepsis Induced by Cecal Ligation and Puncture in Mice. Mediators Inflamm. 2017, 1-12.

Zhou L, Gao M, Xiao Z, Zhang J, Li X, Wang A. (2015). Protective effect of astaxanthin against multiple organ injury in a rat model of sepsis. J Surg Res. 195, 559-567. 